\title{
AKTIVASI KELOMPOK WANITA TANI (KWT) DUSUN MURPEJI LINGSAR MELALUI OPTIMALISASI KEGIATAN BUDIDAYA AYAM KAMPUNG SEBAGAI UPAYA PENINGKATAN EKONOMI RUMAH TANGGA
}

\author{
Naili Rahmawati \\ Universitas Islam Negeri Mataram \\ naili_rahmawati@uinmataram.ac.id
}

\begin{abstract}
Abstrak: Permasalahan kesejahteraan petani dan keluarganya membutuhkan perhatian yang serius dari pemerintah dan lembaga yang terkait. Salah satu program pemerintah yang bertujuan untuk membantu mewujudkan kesejahteraan para petani adalah program Kelompok Wanita Tani (KWT). Tujuan pembentukan Kelompok Wanita Tani (KWT) adalah untuk lebih meningkatkan dan mengembangkan kemampuan petani dan keluarganya sebagai subjek pembangunan pertanian melalui pendekatan kelompok tani agar lebih berperan dalam pembangunan. Peningkatan produktivitas tenaga kerja wanita tani memiliki peran dan potensi yang strategis dalam mendukung peningkatan maupun perolehan pendapatan rumah tangga pertanian di pedesaan. Usaha budidaya ternak ayam kampung yang telah dijalankan oleh Kelompok Wanita Tani (KWT) "Karya Mandiri" di Dusun Murpeji sebenarnya pernah berjalan dan memberikan hasil yang cukup menjanjikan dalam membantu kebutuhan ekonomi keluarga, namun kegiatan tersebut saat ini kembali terkesan berjalan apa adanya seperti sebelumnya dan menunjukkan kondisi yang menurun aktifitasnya. Kegiatan pengabdian ini bertujuan untuk mengaktifkan dan meningkatkan kembali kegiatan Kelompok Wanita Tani (KWT) "Karya Mandiri" Dusun Murpeji dalam budidaya ternak ayam kampung. Pendampingan terhadap Kelompok Wanita Tani (KWT) "Karya Mandiri" Dusun Murpeji ini salah satunya diwujudkan melalui penyelenggaraan program pelatihan (workshop. Keberhasilan kegiatan ini secara garis besar dapat dilihat dari beberapa aspek, antara lain: Pertama, keberhasilan target jumlah peserta pelatihan, kedua, ketercapaian tujuan pendampingan (termasuk penyampaian materi pendampingan sesuai perencanaan), dan ketiga, kemampuan obyek pendampingan dalam penguasaan materi sesuai tujuan pendampingan.
\end{abstract}

Kata Kunci: Aktivasi Kelompok Wanita Tani (KWT), Budidaya Ayam Kampung

\begin{abstract}
Problems with the welfare of farmers and their families require serious attention from the government and related institutions. One of the government programs that aims to help realizing the welfare of farmers is Kelompok Wanita Tani (KWT). Its purose is to further enhance and develop the capabilities of farmers and their families as subjects of agricultural development through a farmer group approach to play a more important role in development. Increasing the productivity of female farm laborers has a strategic role and potential in supporting the increase and income of agricultural households in rural areas. The poultry farming business that has been carried out by the Kelompok Wanita Tani (KWT) "Karya Mandiri" in the Murpeji village has actually run and provided results that are quite promising in supporting the family's economic needs, but these activities now seem to go the way they were before and indicates a condition that decreases its activity. This community service program aims to activate and improve the activities of the Kelompok Wanita Tani (KWT) "Karya Mandiri" in the area in the cultivation of free-range chicken. One of the facilitations for the Kelompok Wanita Tani (KWT) "Karya Mandiri" is realized through the implementation of training programs (workshops). The success of this activity can be broadly seen from several aspects, namely: First, the success of the target number of trainees. Second, achieving the goal of assistance (including the delivery of assistance materials in accordance with planning). Third, the object's ability to assist in mastering the material is according to the purpose of assistance.
\end{abstract}

Keywords: the activation of Kelompok Wanita Tani, the cultivation of Ayam kampung 


\section{Pendahuluan}

Adagium "di balik suksesnya seorang pria atau laki-laki, pasti ada wanita atau perempuan dibelakangnya", menunjukkan posisi perempuan dalam kehidupan bermasyarakat memiliki peran yang sangat penting. Terlebih di zaman sekarang ini dapat dijumpai banyak kaum hawa sebagai motor penggerak berbagai sektor pembangunan, termasuk untuk memajukan dan mensejahterakan bidang pertanian. Salah satu program pemerintah yang bertujuan untuk membantu mewujudkan kesejahteraan para petani adalah dengan menggulirkan program Kelompok Wanita Tani (KWT), di mana tujuannya adalah sebagai wadah untuk lebih meningkatkan dan mengembangkan kemampuan petani dan keluarganya sebagai subjek pembangunan pertanian melalui pendekatan kelompok agar lebih berperan dalam pembangunan. ${ }^{1}$

Melalui pembentukan wadah/organisasi bagi perempuan tani Indonesia ini, maka telah digariskan bentuk-bentuk peran perempuan dalam pembangunan dengan harapan peran mereka dalam pembangunan dapat meningkat. Wanita bukan hanya berperan sebagai ibu rumah tangga pada dunia pertanian, tetapi banyak wanita yang ikut berperan atau memberi kontribusi nyata pada usaha yang diusahakan oleh keluarga mereka. Kenyataanya sekitar 50 persen wanita tani di samping bekerja di rumah sebagai ibu rumah tangga, mereka juga bekerja di ladang atau di sawah bahkan mereka membuka lapangan pekerjaan sendiri dengan mengikuti Kelompok Wanita Tani (KWT). Hal ini dilakukan karena mereka berharap dengan adanya peran atau keterlibatan wanita tani, jumlah produktivitas usaha akan meningkat. ${ }^{2}$

Desa Dasan Geria salah satu desa di Kecamatan Lingsar Kabupaten Lombok Barat Provinsi Nusa Tenggara Barat merupakan desa yang dekat dengan wilayah perkotaan dan menjadi perbatasan antara Kabupaten Lombok Barat dengan Kota Madya Mataram. Kondisi geografis Desa Dasan Geria yang masih berada di wilayah pegunungan menjadi daya tarik tersendiri bagi investor lokal maupun luar daerah untuk menanamkan investasinya di Desa ini. ${ }^{3}$ Salah satu dusun yang ada di Desa Dasan Geria ini adalah Dusun Murpeji yang terletak di atas bukit Murpeji, ${ }^{4}$ di mana sebagian besar (90\%) masyarakat Dusun ini masih memiliki tingkat perekonomian yang masih rendah yang hanya mengandalkan sumber penghasilannya dari kekayaan sumber daya alam sekitar yang dipenuhi pohon aren, pohon kelapa dan pohon-pohon lainnya. Pendapatan rata-rata pendapatan per-bulan warga Dusun Murpeji ini berkisar antara Rp. 1.000.000,- hingga 2.000.000,-..5

\footnotetext{
${ }^{1}$ Kelompok tani merupakan suatu bentuk perkumpulan petani yang berfungsi sebagai media penyuluhan yang diharapkan lebih terarah dalam perubahan aktivitas usaha tani yang lebih baik lagi. Peningkatan produktivitas tenaga kerja wanita tani memiliki peran dan potensi yang strategis dalam mendukung peningkatan maupun perolehan pendapatan rumah tangga pertanian di pedesaan. Badan Pendidikan dan Latihan Penyuluh Pertanian, Gema Penyuluhan Pertanian, No. 34, (Jakarat: Departemen Pertanian Republik Indonesia, 1990), hlm. 23.

2 Loekman Soetrisno, Kemiskinan, Perempuan, \& Pemberdayaan, (Yogyakarta: Kanisius, 1997), hlm. 68.

${ }^{3}$ Dasan Geria Mulai Berbenah. https://kimlombokbaratkab.wordpress.com Diakses tanggal 12 Maret 2017.

4 Penelusuran sejarah menyebutkan bahwa penamaan wilayah ini dengan nama "Murpeji" ini menurut bahasa masyarakat sekitar memiliki arti suatu tempat yang banyak ditumbuhi oleh pohon aren. Istilah kata "peji" sendiri artinya adalah pohon aren yang biasa digunakan oleh masyarakat untuk membuat kolang-kaling atau gula merah (gula aren) untuk bahan makanan dan minuman olahan. Karenanya, masyarakat Dusun Murpeji sebagian besar merupakan petani pengolah pohon aren, baik sebagai penyulin air nira maupun sebagai pengolah bahan air nira tersebut untuk dijadikan gula aren sebagai komoditi utama Dusun ini. Wawancara dengan Kepala Dusun Murpeji, tanggal 08 Pebruari 2017.

5 Ibid.
} 
Positifnya, masyarakat Dusun Murpeji dalam menyikapi program pemerintah ini sangat terbuka selama itu semua mendukung kemajuan masyarakat, terutama dalam menyokong perekonomian rumah tangga penduduk. Keterbukaan masyarakat Dusun Murpeji untuk kemajuan masyarakat juga ditunjukkan dengan adanya peranan ibu-ibu Dusun Murpeji untuk membantu perekonomian keluarga dengan membentuk Kelompok Wanita Tani (KWT) "Karya Mandiri" sebagai penyokong kegiatan para suami atau bapak-bapak dalam melakukan kegiatan sehari-hari, termasuk dalam menggalakkan aktifitas budidya ternak unggas, khususnya ayam kampung. ${ }^{6}$

Usaha budidaya ternak ayam kampung yang telah dijalankan oleh Kelompok Wanita Tani (KWT) "Karya Mandiri" di Dusun Murpeji sebenarnya pernah berjalan dan memberikan hasil yang cukup menjanjikan dalam membantu kebutuhan ekonomi keluarga, ${ }^{7}$ namun kegiatan tersebut saat ini kembali terkesan berjalan apa adanya seperti sebelumnya dan menunjukkan kondisi yang menurun aktifitasnya. ${ }^{8}$ Melihat kondisi tersebut, maka upaya menggairahkan kembali kegiatan Kelompok Wanita Tani (KWT) "Karya Mandiri" Dusun Murpeji untuk budidaya ternak ayam kampung dengan mengoptimalkan kembali (aktivasi) kegiatan tersebut menjadi isu dan fokus pendampingan sekaligus kegiatan ini menjadi tantangan yang sangat menarik (urgen) untuk dilaksanakan dengan pertimbangan bahwa masih banyaknya waktu luang yang dimiliki oleh para ibu-ibu atau perempuan Dusun Murpeji yang tergabung dalam Kelompok Wanita Tani (KWT) "Karya Mandiri" Dusun Murpeji, sehingga akan sia-sia jika waktu yang banyak dan luang tersebut terlewatkan saja dan tidak mampu dimanfaatkan untuk kegiatankegiatan positif, terutama jika dapat membantu untuk peningkatan ekonomi keluarga.

\section{Metode}

Sasaran kegiatan pendampingan adalah seluruh anggota Kelompok Wanita Tani (KWT) "Karya Mandiri" Dusun Murpeji yang berjumlah sekitar 33 orang. Pelibatan pihak-pihak yang berkompeten membutuhkan narasumber yang kompatibel di bidangnya, semisal penyuluh peternakan dari instansi Dinas Peternakan Kabupaten, termasuk dosen atau praktisi yang memiliki pengalaman dan kemampuan untuk memberikan materi terkait, khususnya tentang pembukuan sederhana usaha rumahan.

Model pendekatan yang digunakan dalam kegiatan pendampingan ini dilakukan dengan model pendekatan klasikal dan individual dengan metode yang ceramah bervariasi, demonstarsi dan praktek atau latihan. Adapan metode pengumpulan datanya adalah model dokumentasi, wawancara dan melakukan observasi langsung di lapangan.

\footnotetext{
${ }^{6}$ Potensi pengembangan ayam kampug ini sangat rasional jika dibudidayakan ditengah masyarakat pedesaan. Masjoko, Usaha Meningkatkan Ekonomi Keluarga Dengan Budidaya Ayam Buras, (Jakarta: UNJ Press, 2015), hlm. 4.

7 Potensi pasar untuk ayam kampung tetap lebih menjanjikan karena potensi pasar yang masih bagus. Kondisi pasar yang ada menggambarkan bahwa produksi ayam kampung yang masih jauh dibawah permintaan juga merupakan peluang bagi peningkatan dan pengembangan pengusahaannya, dimana sebagian besar $(72,5 \%)$ ketersediaannya masih berasal dari ayam ras. Kontribusi daging ayam Kampung (tahun 2008) sekitar $16,1 \%$ dibandingkan dengan daging ayam ras sekitar $42,4 \%$ terhadap penyediaan daging nasional yang menurun menjadi sekitar $11 \%$ pada tahun 2010. Direktorat Jenderal Peternakan, Statistik Peternakan Kementerian Pertanian RI, (Jakarta: Ditjenak, 2010), hlm. 123.

${ }^{8}$ Wawancara dengan Ketua KWT Dusun Murpeji, tanggal 16 Pebruari 2017.
} 


\section{Hasil dan Pembahasan}

Pelaksanaan kegiatan penelitian dan pengabdian kepada masyarakat di Dusun Murpeji ini dimulai dengan tahapan-tahapan, antara lain:

\section{Perencanaan Kegiatan}

Perencanaan pelaksanaan kegiatan pendampingan ini dapat dilihat pada tabel 1 berikut:

Tabel 1. Rencana Kegiatan

\begin{tabular}{|c|c|c|}
\hline No. & Jenis Kegiatan & Keterangan \\
\hline 1. & Kunjungan pra kegiatan pendampingan. & $\begin{array}{l}\text { Kebutuhan proposal kegiatan } \\
\text { pendampingan }\end{array}$ \\
\hline 2. & $\begin{array}{l}\text { Kunjungan dalam rangka observasi, wawancara } \\
\text { dan dokumentasi bahan yang terkait. }\end{array}$ & $\begin{array}{l}\text { Pengumpulan data organisasi dan } \\
\text { kegiatan. }\end{array}$ \\
\hline 3. & $\begin{array}{l}\text { Persiapan pelaksanaan kegiatan pelatihan } \\
\text { (workshop) pendampingan terhadap Kelompok } \\
\text { Wanita Tani (KWT) "Karya Mandiri" Dusun } \\
\text { Murpeji. }\end{array}$ & $\begin{array}{l}\text { Pengolahan data-data, koordinasi } \\
\text { dengan pemateri, konsumsi, ATK dll. }\end{array}$ \\
\hline 4. & $\begin{array}{l}\text { Pelaksanaan kegiatan pelatihan (workshop) } \\
\text { pendampingan terhadap Kelompok Wanita Tani } \\
\text { (KWT) "Karya Mandiri" Dusun Murpeji. }\end{array}$ & $\begin{array}{l}\text { Tempat kegiatan di Balai Pertemuan } \\
\text { Kelompok Wanita Tani (KWT) "Karya } \\
\text { Mandiri" Dusun Murpeji. }\end{array}$ \\
\hline 5. & $\begin{array}{l}\text { Monitoring dan evaluasi hasil kegiatan } \\
\text { pendampingan terhadap Kelompok Wanita Tani } \\
\text { (KWT) "Karya Mandiri" Dusun Murpeji. }\end{array}$ & $\begin{array}{l}\text { Tempat kegiatan di rumah-rumah } \\
\text { anggota Kelompok Wanita Tani (KWT) } \\
\text { "Karya Mandiri" Dusun Murpeji. }\end{array}$ \\
\hline 6. & $\begin{array}{l}\text { Pembuatan laporan akhir kegiatan } \\
\text { pendampingan terhadap terhadap Kelompok } \\
\text { Wanita Tani (KWT) "Karya Mandiri" Dusun } \\
\text { Murpeji. }\end{array}$ & $\begin{array}{l}\text { Penyusunan laporan, legalisasi, } \\
\text { penggandaan dll. }\end{array}$ \\
\hline
\end{tabular}

\section{Kunjungan}

Kunjungan pendamping dalam merealisasikan kegiatan ini dilaksanakan sesuai dengan jadwal yang sudah dibuat sebelumnya., yaitu:

a. Kunjungan pra kegiatan untuk penyusunan bahan proposal kegiatan.

b. Kunjungan dalam rangka observasi, wawancara dan dokumentasi bahan yang terkait tentang rencana kegiatan.

c. Kunjungan dalam rangka persiapan pelaksanaan kegiatan pelatihan (workshop) pendampingan.

d. Kunjungan evaluasi pasca kegiatan pelatihan (workshop) pendampingan.

\section{Persiapan Kegiatan Pelatihan (Workshop)}

Persiapan kegiatan pelatihan (workshop) ini antara lain dengan dengan melakukan pengolahan data awal, selain untuk melengkapi persiapan konsumsi, ATK, pembuatan undangan, pemasangan spanduk untuk persiapan pra kegiatan pelatihan (workshop) dan sebagainya.

\section{Kegiatan Pelatihan (Workshop)}

Kegiatan pelatihan (workshop) tentang Aktivasi Kelompok Wanita Tani (KWT) Dusun Murpeji-Lingsar Melalui Optimalisasi Kegiatan Budidaya Ayam Kampung Sebagai Upaya Peningkatan Ekonomi Rumah Tangga dilaksanakan selama 2 hari, yaitu pada tanggal 30 dan 31 Agustus 2017 dengan mengambil tempat di Balai Pertemuan Kelompok Wanita Tani (KWT) "Karya Mandiri" Dusun Murpeji dengan jumlah undangan sebanyak 33 peserta yang berasal dari 
Pengurus dan anggota Kelompok Wanita Tani (KWT) "Karya Mandiri", dan dalam waktu pelaksanaan dihadiri oleh 33 peserta.

Kegiatan ini dibagi menjadi dua (2) sesi/hari, yaitu:

a. Sesi/hari pertama dimulai dari pukul yang merupakan sesi penyampaian materi kegiatan pelatihan (workshop) yang diisi oleh Pendamping dan Pemateri/Nara Sumber Utama dari Petugas Penyuluh, yaitu Bapak Ardina Riza, yang merupakan Penyuluh Penyelia pada Dinas Pertanian dan Peternakan Kabupaten Lombok Barat. Materi yang disampaikan pada kegiatan pelatihan (workshop) tentang Aktivasi Kelompok Wanita Tani (KWT) Dusun Murpeji-Lingsar Melalui Optimalisasi Kegiatan Budidaya Ayam Kampung Sebagai Upaya Peningkatan Ekonomi Rumah Tangga, antara lain: teknis pembuatan kandang yang baik dan benar, teknis pembibitan yang benar dan prospektif, teknis pembuatan pakan yang mudah dan murah, teknis perawatan yang baik dan benar, strategi pemasaran hasil produksi, dan pembukuan kegiatan usaha budidaya ayam kampung.

b. Sesi/hari kedua dimulai dari pukul yang merupakan sesi interaktif dan latihan (praktek). Dalam sesi ini, banyak muncul pertanyaan dari para peserta yang secara umum antusias terhadap kegiatan ini. Monitoring dan Evaluasi Kegiatan

c. Kegiatan evaluasi dan monitoring terhadap hasil pendampingan ini dilakukan dengan kunjungan ke obyek dampingan untuk melihat secara langsung hasil kegiatan.

\section{Peremajaan Kandang}

Kondisi kandang saat ditemui saat visitasi terkesan tidak pernah tersentuh untuk dibersihkan, sehingga kondisi kandang akan rentan penyakit atau sesuatu yang dapat menghambat pertumbuhan ayam kampung tersebut. Berikut gambar kondisi kandang yang ditemukan saat visitasi dan observasi lapangan:

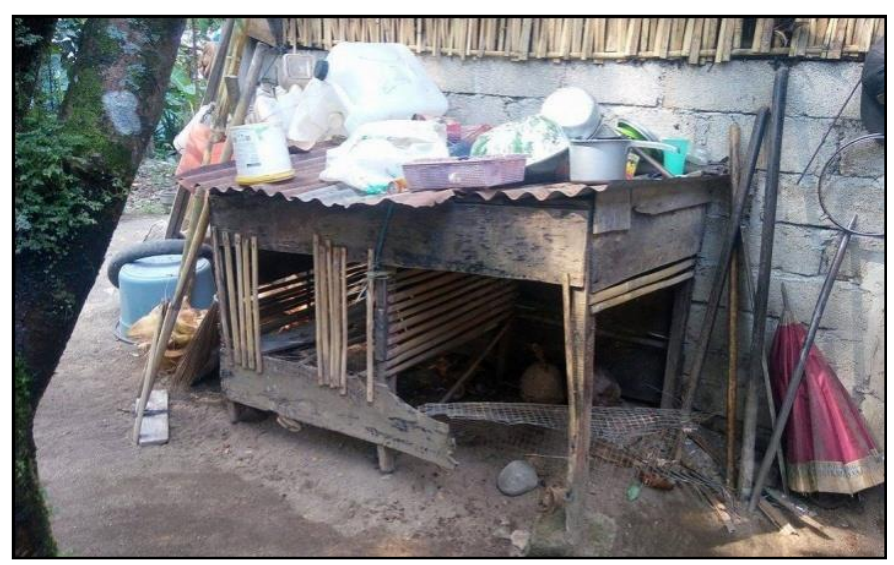

Gambar 1. Kondisi kandang yang rusak

Melihat kondisi yang ada tersebut, melalui kegiatan ini Pemateri atau narasumber kembali melakukan penyuluhan dengan memberikan informasi tentang pentingnya kondisi kandang yang bersih dan sehat untuk menjamin pertumbuhan ayam kampung budidaya, terutama bagi pertumbuhan anak ayam yang belum berumur 1 bulan. Pemateri langsung mempraktekkan kembali pembuatan kandang ayam dengan memanfaatkan sumber daya sekitar seperti bambu sebagai bahan utamanya. Berikut gambar praktek pembuatan kandang ayam kampung sederhana: 


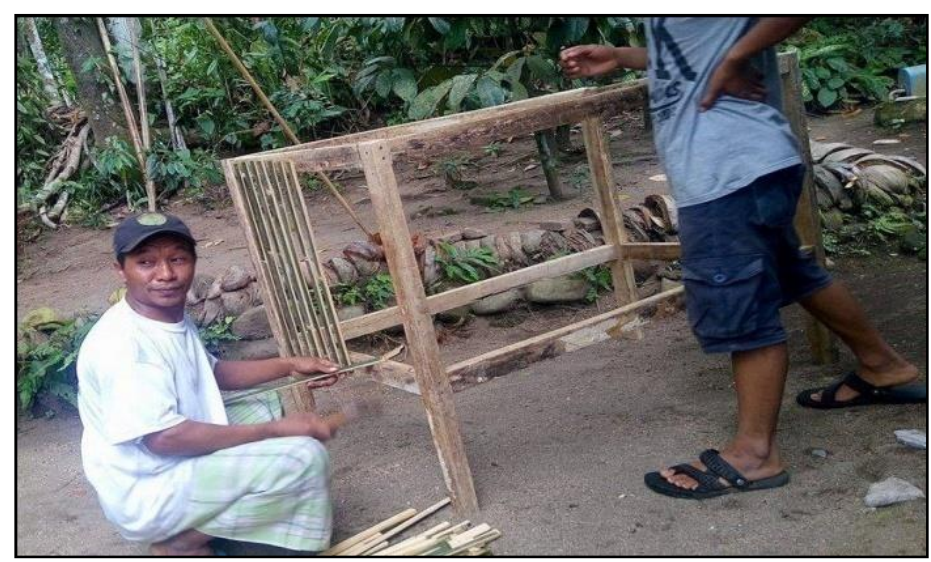

Gambar 2. Proses Pembuatan Rangka Kandang

Kandang ayam bisa diibaratkan seperti rumah manusia. Karena itu, dalam pembuatannya perlu dipikirkan mengenai kenyamanan, keamanan, dan kelayakannya agar ayam bisa tumbuh dan berkembang secara optimal. Cara membuat kandang ayam kampung pun tak harus bagus serta mahal. Peternak harus memperhatikan syarat kelayakan kandang, yaitu kuran kandang, letak dan arah kandang, dan konstruksi kandang. ${ }^{9}$

Selain dengan membuatkan kandang yang sederhana tersebut, budidaya ayam kampung untuk ayam-ayam yang diumbar, harus dan sebaiknya disediakan kandang tempat berteduh dari terik matahari, guyuran air hujan dan bermalam. Ukuran kandang tergantung jumlah ayam dan luasan lahan tersedia. Kandang tersebut terbuat dari dinding bambu dengan atap rumbia, genteng atau seng, kemudian diberi pintu yang dilengkapi dengan kunci. Termasuk juga di dalamnya harus dibuatkan sangkar tempat bertelur dan mengeram berdiameter $40 \mathrm{~cm}$ harus disediakan cukup untuk sejumlah ayam induk yang dipelihara, terlindung dari air hujan dan terik matahari. Lantai sangkar biasanya diisi dengan tangkai padi kering atau rumput kering. ${ }^{10}$

\section{Pembibitan Berkualitas}

Pembibitan dalam budidaya ayam kampung merupakan tahapan yang juga sangat menentukan dalam menunjang keberhasilan peternak untuk menghasilkan ayam kampung yang berkualitas. Masyarakat Dusun Murpeji dalam melakukan pembibitan ayam kampung ternakannya masih menggunakan metode konvensional, yakni membiarkan ayam jantan dengan ayam betina melakukan perkawinan secara alamiah, termasuk juga pada saat tahapan penetasan telur (peng-eraman) dibiarkan secara alami saja. ${ }^{11}$ Padahal, sebelumnya para anggota KWT "Karya Mandiri" Dusun Murpeji pernah diberikan dan mempraktekkan teknis pengawinan dan penetasan telur ayam yang akan dijadikan bibit ayam kampung.

Melihat kondisi yang kembali seperti semula, Narasumber saat memberikan materi kembali mencoba untuk mempraktekkan teknik untuk mendapatkan bibit ayam kampung berkualitas.

\footnotetext{
${ }^{9}$ http://ayamkampungpro.blogspot.co.id/2013/11/cara-membuat-kandang-ayam-kampung-bagian-i-kelayakankandang.html. Diakses tanggal 12 September 2017.

${ }^{10}$ Sofjan Iskandar, Usaha Tani Ayam Kampung, (Bogor: Balai Peneltian Ternak Ciawi, 2010), hlm. 10.

${ }^{11}$ Penetasan telur untuk bibit ayam kampung hanya dibiarkan begitu saja secara alami. MIsalkan ayam betina bertelur sebanyak 10 biji, maka sekitar 7 biji dieramkan oleh induknya. Terkadang telur tersebut dapat ditetaskan semuanya, terkadang hanya setengah saja yang bisa ditetaskan. Wawancara dengan Anggota KWT "Karya Mandiri" Dusun Murpeji, Ibu Sahmin, tanggal 12 Agustus 2017.
} 


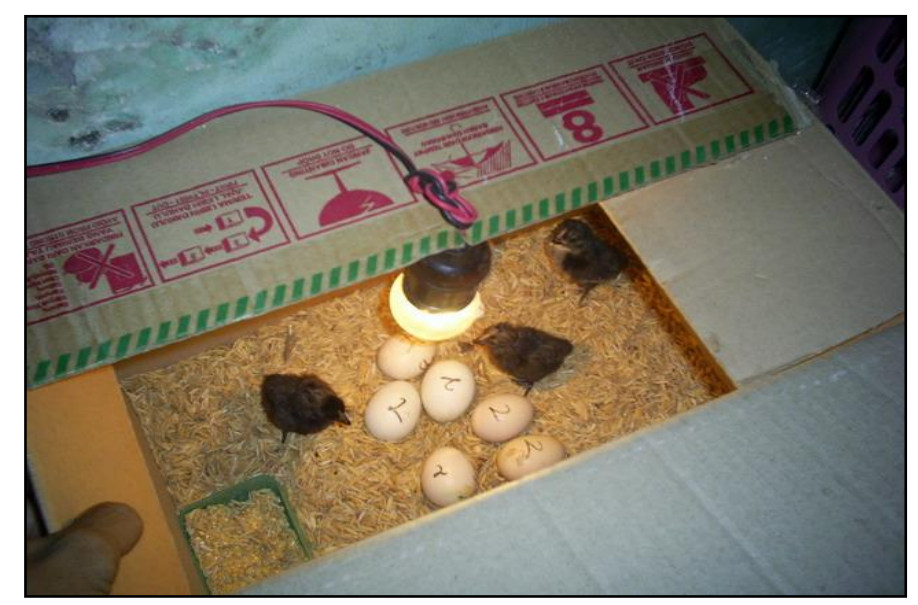

Gambar 3. Praktek Penetasan Telur dalam Inkubator

Pemateri dalam ceramahnya menjelaskan bahwa paling tidak ayam betina yang bagus dijadikan bibit indukan adalah seekor ayam betina dewasa muda baru bertelur sekali, umur 79 bulan, sehat, lincah, penampilan tegap, bulu halus mengkilap, mata bening dan bulat, tidak suka mematok betina lain (kanibal) dan tidak pernah terserang penyakit menular. Dan untuk ayam pejantannya, kriterianya adalah seekor jago dewasa mampu kawin berumur 1-2 tahun, sehat, lincah, penampilan tegap, bulu halus mengkilap mata bening dan bulat, tidak mematok betina di dekatnya dan tidak pernah terserang penyakit menular. ${ }^{12}$ Bibit ayam yang idealnya dapat diperoleh dari tetangga (kalau ada) agar sudah terbiasa dengan lingkungan baru di halaman kita. Namun apabila diperoleh jauh, dari pasar misalnya, maka diperlukan beberapa penanganan persiapan sebelum dilepas. Penanganan ini sangat dianjurkan selain untuk memperkuat ketahanan tubuh ayam, juga untuk mencegah penularan penyakit terhadap lingkungan baru.

\section{Pembuatan Pakan Murah dan Berkualitas}

Pakan ayam dalam budidaya ayam merupakan hal yang terpenting yang dapat mempengaruhi tumbuh kembang ayam budidaya. Anggota KWT "Karya Mandiri" Dusun Murpeji dalam memberikan makanan ke ternak ayamnya tidak terlalu memperhatikan hal-hal teknis yang sangat diperlukan, seperti komposisi gizi dan lainnya. Pemberian pakan ayam terkadang dilakukan karena hal ini sangat terkait dengan bagaimana memperoleh pakan ayam tersebut, yaitu mereka harus membeli dengan harga yang lumayan menguras kantong rumah tangga mereka. ${ }^{13}$

Karenanya, dalam kesempatan pelatihan ini, pemateri yang merupakan praktisi dan penyuluh di Dusun ini sekalihgus memberikan materi bagaimana membuat pakan ayam yang murah dan berkualitas dengan memanfaatkan bahan baku yang ada di sekitar semisal daun papaya, daun kangkung liar dan juga mengkombinasikannya dengan biji jagung tumbuk yang juga merupakan hasil kebun warga Dusun Murpeji.

\footnotetext{
12 Materi Pelatihan Aktivasi Kelompok Wanita Tani (KWT) Dusun Murpeji-Lingsar Melalui Optimalisasi Kegiatan Budidaya Ayam Kampung Sebagai Upaya Peningkatan Ekonomi Rumah Tangga, tanggal 02 September 2017.

13 Harga pakan ayam yang lumayan mahal mendekati harga beras membuat kami sangat berat untuk membelinya, sehingga kami hanya membiarkan ayam peliharaan kami bekeliaran secara alami. Wawancara dengan Anggota KWT "Karya Mandiri" Dusun Murpeji, Ibu Munisah, tanggal 12 Agustus 2017.
} 


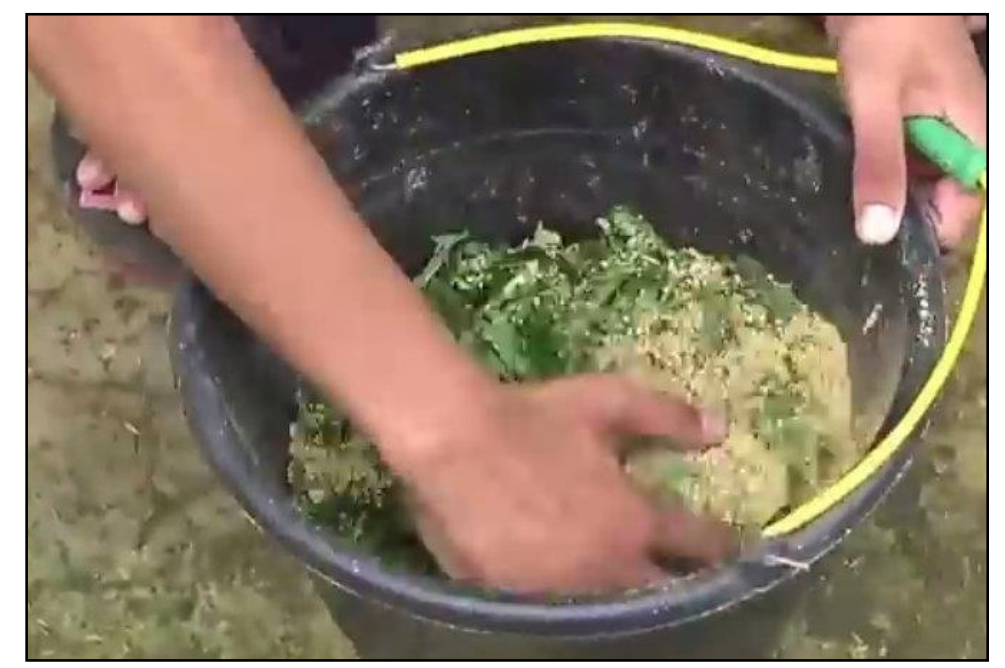

Gambar 4. Pencampuran Jagung Tumbuk Untuk Campuran Utama

Pembuatan pakan yang murah dengan menggunakan bahan baku yang banyak tersedia di sekitar rumah warga sangat membantu untuk menyediakan pakan yang berkualitas. Pemberian pakan yang tidak seimbang baik kualitas maupun kuantitasnya akan menurunkan produktivitas dan reproduktivitas ayam Kampung. Tingkat produktivitas dan reproduktivitas ayam Kampung beragam, bergantung pada sistem pemeliharaan dan keragaman individu Ayam Kampung umumnya memiliki kebiasaan berkeliaran sepanjang hari di alam bebas dan mencari makan pada timbunan sampah, selokan, tepi saluran air dan jalan. Hal tersebut berkaitan erat dengan kinerja reproduksi yang menurun secara nyata akibat perkawinan in breeding secara terusmenerus. $^{14}$

Faktor utama penyebab kegagalan model pengembangan ternak ayam Kampung di pedesaan adalah rendahnya kandungan protein pakan dan kurangnya kesadaran peternak dalam melaksanakan pengendalian penyakit, terutama ND, cacingan, dan kutu. ${ }^{15}$ Upaya optimalisasi produksi ayam Kampung salah satunya dapat dilakukan dengan perbaikan pakan dan membuat pakan murah dengan tetap memperhatikan kandungan zat-zat nutrien di dalamnya. Penyusunan pakan ayam Kampung pada prinsipnya sama dengan pakan ayam ras, yaitu membuat pakan dengan kandungan gizi sesuai dengan kebutuhan ayam agar pertumbuhan daging dan produksi telur sesuai dengan yang diharapkan. ${ }^{16}$

\section{Optimalisasi Pemeliharaan dan Perawatan}

Sebagaimana hasil survey dan observasi sebelumnya, sebagian besar ayam kampung yang dimiliki warga anggota KWT "Karya Mandiri" Dusun Murpeji dilepas atau diumbar begitu saja di halaman sekitar, sehingga kualitas pemeliharaan dan perwatan yang diperoleh tidak maksimal.

14 T. Sartika, Peningkatan Mutu Bibit Ayam Kampung melalui Seleksi dan Pengkajian Penggunaan Penanda Genetik Promotor Pralaktin dalam Mas Market Assiated Selection untuk Mempercepat Proses Seleksi, Disertasi, (Bogor: Sekolah Pascasarjana Institut Pertanian Bogor, 2005), hlm. 133.

15 Gunawan dan M.M.S. Sundari, Pengaruh Penggunaan Probiotik Dalam Ransum Terhadap Produktivitas Ayam. (Wartazoa, 2003) hlm. 92-98.

${ }^{16}$ A.P. Sinurat, Penggunaan Bahan Pakan Lokal Dalam Pembuatan Ransum Ayam Buras, (Wartazoa, 1999), hlm. $12-20$. 
Optimalisasi pemeliharaan ayam kampung dapat dilakukan dengan beberapa cara, antara lain: ${ }^{17}$

a. Untuk memudahkan pengenalan, ayam-ayam sebaiknya diberi tanda atau biasanya kita mengenali dari ciri-ciri tampilannya.

b. Untuk ayam kampung diumbaran, guna perlindungan terhadap cuaca dingin, hujan dan/ atau terik matahari perlu dibuatkan tempat untuk mempertahankan daya tahan tubuh ayam, sehingga tidak mudah sakit atau mati, karena sakit dan kematian ini merupakan faktor yang sangat merugikan mangingat jumlah pemilikan relatif sedikit. Pada malam hari sebaiknya ayam dikandangkan dan pagi hari bisa dilepas kembali.

c. Vaksinasi terhadap penyakit tetelo (ND=Newcastle desease) sebaiknya dilakukan teratur.

d. Melakukan pengamatan pada ayam-ayam sangat penting terutama apabila ada ayam-ayam yang sakit atau kurang sehat, yang dipelihara khusus terpisah dari ayam-ayam sehat.

e. Dalam rangka mempertahankan mutu, ayam-ayam yang dipilih, baik itu untuk dijual maupun dipotong untuk konsumsi keluarga, sebaiknya ayam yang dijual jangan ayam yang paling bagus, karena dapat dipakai lagi sebagai induk-induk atau jago yang dapat menurunkan bibit yang baik.

f. Begitu juga dengan telur untuk dijual dan/ atau konsumsi sendiri, sebaiknya dipilih telurtelur dengan bentuk-bentuk tidak baik seperti bulat, telalu lonjong, berkulit kasar, serta ukuran yang kecil. Sementara telur-telur bagus dan besar-besar sebanyak 7 butir dapat ditetaskan untuk memproduksi anak ayam.

\section{Pemasaran Usaha}

Hasil wawancara dengan salah satu warga yang merupakan anggota KWT "Karya Mandiri" Dusun Murpeji menyebutkan bahwa masyarakat sekitar jika ingin menjual hasil ternak ayam kampungnya tinggal menunggu datangnya penjual yang secara rutin mendatangi warga sekitar. Dalam masalah harga, penentuan sangat tergantung pada kondisi dan tawar menawar yang terjadi dalam transaksi saat itu. ${ }^{18}$

Melihat praktek pemasaran hasil budidaya ayam kampung warga Murpeji tersebut, tentunya kuantitas jual yang ada sangat terbatas hanya dengan mengandalkan pedagang eceran sebagai pengepul yang datang secara temporari. Permasalahan terkait pemasaran ini merupakan permasalahan non teknis dalam budidaya ayam kampug. Sesuatu hal yang wajar jika muncul pertanyaan yang terlintas sebelum beternak ayam kampung biasanya adalah "Kemana harus saya jual?". Pertanyaan inilah yang harus kita temukan jawabannya.

Ada dua langkah yang biasa diambil oleh seorang peternak, yang pertama adalah menjualnya kembali kepada pelaku bisnis penampung ayam atau menjualnya sendiri. Dua hal ini memiliki nilai positif dan negatifnya sendiri. Jika saat panen tiba kita mengambil langkah ada pembeli yang siap menampung hasil ternak, yang menjadi dasar utama biasanya adalah harga. Karena ayam ini untuk dijual lagi, pasti harga yang kita berikan lebih rendah. Tapi kita tidak

\footnotetext{
17 Sofjan Iskandar, Usaha..., Op., Cit., hlm. 12.

18 Wawancara dengan anggota KWT "Karya Mandiri" Dusun Murpeji, Ibu Warni, tanggal 14 Agustus 2017.
} 
perlu repot-repot mencari pembeli diluar atau repot menjual hasil ternak kita ke pasaran. Dalam istilah ternak biasa di sebut dijual ke Bakul.

Berbeda jika kita mencari pasar sendiri. Yang pertama kita lakukan adalah analisa pasar. Setelah kita analisa pasar, kita harus memulai ternak sekalipun dari skala kecil. Setelah itu, kita bisa mendatangi restoran-restoran, atau pedagang ayam di pasar, mungkin juga bisa mendatangi pabrik jagal ayam untuk mencari celah jual jika nanti panen tiba. Kelebihan dari mencari pembeli sendiri adalah dimasalah harga. Kita tidak harus menerapkan harga minimum, yang perlu kita lakukan adalah negosiasi dengan pembelinya. Selama harga cocok, proses jual beli akan menemui kesepakatan.

\section{Pencatatan atau Laporan Keuangan Usaha}

Usaha rumahan memang terkesan sangat jauh dari manajemen yang baik, termasuk di dalamnya bagaimana mencatat hasil usaha dan pengeluaran operasionalnya. Sebagian besar warga Dusun Murpeji yang menjadi anggota KWT "Karya Mandiri" Dusun Murpeji mengaku tidak pernah sama sekali melakukan pencatatan atau membuat buku laporan tentang usaha yang dijalankan, baik budidaya ayam kampung ataupun usaha lainnya seperti usaha gula aren dan sebagainya. Mereka dalam keseharian hanya mengetahu bahwa jika menjual hasil usahanya, selanjutnya hanya digunakan untuk memenuhi kebutuhan hidup sehari-hari tanpa mempedulikan apakah ini bagian dari modal ataupun biaya operasional yang harus dicatat. ${ }^{19}$

Tentunya praktek seacam ini tidak dapat disalahkan begitu saja, terkait dengan kebiasaan dan kondisi keuangan warga. Akan tetapi untuk membiasakan diri berjalan dan bertindak professional, terutama untuk mengembangkan suatu usaha, pencatatan dan pelaporan arus kas sangat-sangat dibutuhkan untuk mengetahui proyeksi dan prosfektifitas usaha yang digeluti. Terkai dengan hal tersebut, pengabdi yang sekaligus pemateri telah memberikan pelatihan untuk membuat catatan kecil berupa laporan keuangan usaha rumahan sederhana sebagaimana gambar berikut:

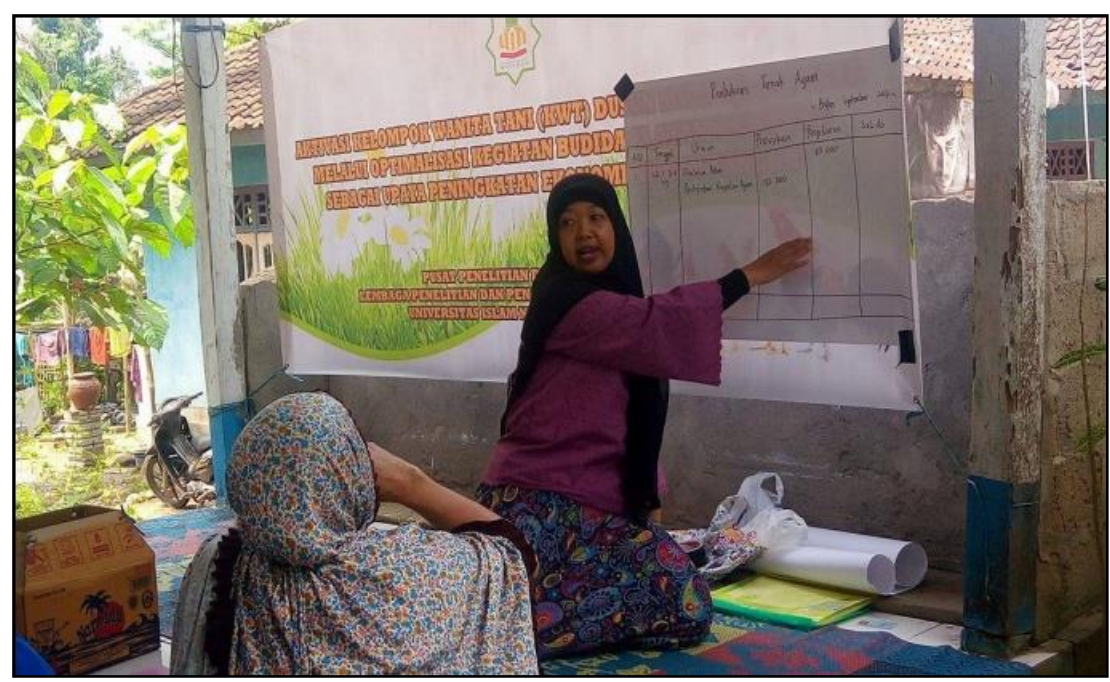

Gambar 5. Pemberian Materi Pembuatan Laporan Keuangan Sederhana

${ }^{19}$ Wawancara dengan anggota KWT "Karya Mandiri" Dusun Murpeji, Ibu Warni, tanggal 14 Agustus 2017. 
Pencatatan keuangan secara luas digunakan sebagai pelaporan transaksi yang terjadi dalam harian, mingguan, dan bulanan. Hasil catatan tersebut, akan menjadi sebuah financial report bagi bisnis yang Anda miliki. Laporan tersebut-lah yang menjadi acuan untuk melihat kondisi bisnis yang tengah dijalankan. Pencatatan sangat penting, terlebih untuk menghindari hal-hal yang tidak diinginkan. Banyak pelaku bisnis pemula yang sering melupakan catatan keuangan bisnis yang sedang mereka jalankan. Ketika usaha seseorang semakin maju dan membutuhkan modal, ketika melakukan pengajuan pinjaman ke bank, laporan keuangan bisnis itulah yang akan dilihat oleh pihak perbankan. Oleh karena itu, instrument ini harus rapi melakukan pencatatan keuangan secara berkala dari awal.

Sebagai pelaku bisnis, maka kita dituntut untuk bisa membuat sebuah pencatatan dan financial report. Meskipun bukan seorang lulusan jurusan akuntansi, tetapi pencatatan dan laporan keuangan harus dipelajari secara otodidak. Hasil dari financial report tersebutlah yang akan menjadi acuan untuk menerapkan sebuah strategi selanjutnya. Tanpa adanya financial report, maka akan sulit menentukan sebuah strategi yang bisa diterapkan untuk bisnis yang dijalankan. ${ }^{20}$

\section{Kesimpulan}

Beberapa kesimpulan dalam kegiatan ini antara lain:

1. Bahwa kegiatan aktivasi ini berjalan lancer sesuai dengan rencana dan kegiatan yang berjalan dapat memenuhi target yang ditetapkan atau diharapkan sebelumnya, yakni sebagian besar anggota Kelompok Wanita Tani (KWT) Dusun Murpeji-Lingsar kembali menggerakkan aktifitasnya untk membudidayakan ternak ayam kampung sebagai salah satu usaha yang menunjang peningkatan taraf ekonomi rumah tangga mereka.

2. Salah satu program pendampingan yaitu penyelenggaraan pelatihan tentang "Aktivasi Kelompok Wanita Tani (KWT) Dusun Murpeji-Lingsar Melalui Optimalisasi Kegiatan Budidaya Ayam Kampung Sebagai Upaya Peningkatan Ekonomi Rumah Tangga" dapat terlaksana dengan baik dan berjalan dengan lancar sesuai dengan rencana kegiatan yang telah disusun. Keberhasilan kegiatan ini secara garis besar dapat dilihat dari beberapa aspek:

a. Keberhasilan target jumlah peserta pelatihan.

b. Ketercapaian tujuan pendampingan (termasuk penyampaian materi pendampingan sesuai perencanaan).

c. Kemampuan obyek pendampingan dalam penguasaan materi sesuai tujuan pendampingan.

\section{Referensi}

Badan Pendidikan dan Latihan Penyuluh Pertanian, 1990, Gema Penyuluhan Pertanian, No. 34, Jakarat, Departemen Pertanian Republik Indonesia.

Biyatmoko, Permodelan Usaha Pengembangan Ayam Buras dan Upaya Perbaikannya di Pedesaan, Makalah Temu Aplikasi Paket Teknologi Pertanian Subsektor Peternakan, Banjarbaru, 2003.

${ }^{20}$ Wawancara dengan anggota KWT "Karya Mandiri" Dusun Murpeji, Ibu Warni, tanggal 14 Agustus 2017. 
Direktorat Jenderal Peternakan, Statistik Peternakan Kementerian Pertanian RI, Jakarta, Ditjenak, 2010.

Direktorat Jenderal Peternakan, Statistik Peternakan Kementerian Pertanian RI, Jakarta, Ditjenak, 2010.

Elizabeth, Roosganda, dan S. Rusdiana, Perbaikan Manajemen Usaha Ayam Kampung Sebagai Salah Satu Sumber Pendapatan Keluarga Petani di Pedesaan, Workshop Nasional Unggas Lokal 2012, (Pusat Penelitian dan Pengembangan Peternakan, Bogor, 2012.

Gunawan, dan M.M.S. Sundari, Pengaruh Penggunaan Probiotik Dalam Ransum Terhadap Produktivitas Ayam, Wartazoa , 2003

http://ayamkampungpro.blogspot.co.id/

http://www.galeripustaka.com/

https://kimlombokbaratkab.wordpress.com

Hutajulu, A.T., Peranan Wanita Dalam Pembangunan (Suatu Pengantar), Medan, Fakultas Pertanian USU, 2004.

Iskandar, Sofjan, Usaha Tani Ayam Kampung, Bogor, Balai Peneltian Ternak Ciawi, 2010.

Mardikanto, T., Penyuluhan Pembangunan Kehutanan, Jakarta, Pusat Penyuluhan Kehutanan Republik Indonesia, 1996

Masjoko, Usaha Meningkatkan Ekonomi Keluarga Dengan Budidaya Ayam Buras, Jakarta, UNJ Press, 2015.

Mongid, A., Gerakan Pembangunan Keluarga Sejahtera, Jakarta,: BKKBN, 1995.

Sartika, T., Peningkatan Mutu Bibit Ayam Kampung melalui Seleksi dan Pengkajian Penggunaan Penanda Genetik Promotor Pralaktin dalam Mas Market Assiated Selection untuk Mempercepat Proses Seleksi, Disertasi, Bogor, Sekolah Pascasarjana Institut Pertanian Bogor, 2005.

Sinurat, A.P., Penggunaan Bahan Pakan Lokal Dalam Pembuatan Ransum Ayam Buras, Wartazoa, 1999.

Soetrisno, Loekman, Kemiskinan, Perempuan, \& Pemberdayaan, Yogyakarta, Kanisius, 1997.

Soewondo, Nani, Domestika Perempuan Dalam Karir, Berkala, Pesantren, No. 2/Vol. VI, 1989.

Sudjarwo, Model-model Pembelajaran, Yogyakarta, Venus Gold Press, 2011.

Suryana dan E.S. Rohaeni, Upaya Perbaikan Sistem Usaha Tani Ayam Buras Dengan Teknologi Inseminasi Buatan di Lahan Kering (Desa Rumintin, Kabupaten Tapin, Kalimantan Selatan), Pros. Seminar Nasional Lahan Kering BPTP Kalimantan Selatan bekerjasama dengan Balai Besar Pengkajian dan Pengembangan Teknologi Pertanian, Bogor, 2006.

Wahyu, Asri, Peran Ibu Rumah Tangga Dalam Meningkatkan Kesejahteraan Keluarga (Studi Kajian Pemenuhan Kebutuhan Pendidikan Anak Pada Ibu Pedagang Jambu Biji Di Desa Bejen Kecamatan Bejen Kabupaten Temanggung), Skripsi, Semarang, Fakultas Ilmu Pendidikan UNNES, 2013.

Welsh, J.L., Combaining Technology And Management To Establish A Modern Animal Husbandry Industry, Makalah Seminar Nasional Industri Peternakan, Jakarta, 1995.

Welsh, J.L., Combaining Technology And Management To Establish A Modern Animal Husbandry Industry, Makalah Seminar Nasional Industri Peternakan, Jakarta, 1995. 